\title{
Invandrare och socialbidrag
}

\author{
EVA FRANZÉN
}

\begin{abstract}
Invandrargruppernas socialbidragstagande har debatterats under den senaste tiden. Diskussionen har ofta handlat om huruvida invandrargrupperna kommer att bli permanenta socialbidragstagare eller om de i takt med ökad tid i landet lyckas bli självförsörjande. Hittills har kunskapen om dynamiken bland olika invandrargruppers socialbidragstagande dock varit begränsad. I denna artikel presenteras socialbidragstagandet för olika invandrare med olika ursprung och bl.a. hur bidragsmottagandet påverkas av vistelsetiden i nya landet.
\end{abstract}

Under den senaste tiden har uppmärksamheten riktats mot de olika invandrargruppernas socialbidragstagande. Det ökade intresset för invandrarnas integrationsprocess kan ses som ett resultat av att andelen invandrare bland socialbidragstagarna ökat dramatiskt samt ökade kostnader för dessa grupper. Följderna av utanförskap och marginalisering har också diskuterats intensivt. Den senare tidens utveckling på arbetsmarknaden tenderar att drabba invandrargrupperna hårdare än övriga. Allt fler invandrare hänvisas till socialbidrag och dessutom under allt längre perioder.

Genom att socialbidragsforskningen i

Eva Franzén har tidigare arbetat som bl.a. flyktingsamordnare och är numera doktorand vid Institutionen för socialt arbete, Göteborgs Universitet och innehar en SFR finansierad doktorandtjänst med inriktning mot fattigdomsoch fördelningsfrågor.
Sverige har intensifierats under senare tid (Halleröd 1991, Salonen 1993, Socialstyrelsen 1995) har komplexiteten i bidragsmottagandet framträtt. Till skillnad från den traditionella bilden av en socialbidragstagare som under längre tid, eller kanske till och med permanent, mottar socialbidrag vet vi idag att socialbidragstagaren ofta endast tillfälligt eller kortvarigt är beroende av socialbidrag för sin försörjning (Gustafsson 1984, 1986).

Men kunskapen om invandrares bidragsberoende är liten. Först i mitten på 60-talet uppmärksammades invandrarnas socialbidragsbehov och en registrering av registerledarens nationalitet i den officiella socialbidragsstatistiken kom till stånd.

Denna artikel grundas på forskning finansierad av Socialvetenskapliga forskningsrådet (SFR). 
1990 infördes en ytterligare uppdelning i flyktingar respektive invandrare utan flyktingstatus, för att möjliggöra en uppföljning av dessa personers hjälpbehov. Detta blev allt mer angeläget då antalet flyktingar blev fler och hjälpbehovet ökade i allt högre takt.

Den kunskap som idag finns om invandrares socialbidragstagande baseras nästan utan undantag på personernas medborgarskap. Den offentliga socialbidragsstatistiken utgår dessutom från årliga tvärsnittsdata. Den befintliga kunskapen om invandrarnas socialbidragstagande måste därmed anses som bristfällig. Det medför dessutom att kunskapen om invandrarnas socialbidragstagande i förhållande till den infödda befolkningen också får bedömas som otillfredsställande.

Det finns ett flertal skäl till varför det är angeläget att öka kunskapen om invandrargruppernas socialbidragsmottagande. En aspekt som ofta framhålls är det kommunalekonomiska perspektivet. I takt med kommunernas försämrade ekonomi och stigande kostnader för socialbidrag har intresset riktats mot invandrargruppen. Det är därför intressant att närmare studera denna klientgrupps socialbidragsmottagande i förhållande till andra grupper. Dessutom är det naturligtvis angeläget att öka kunskapen om socialtjänstens klienter av vilken invandrargruppens andel är betydande. Det kan även vara motiverat att studera invandrarnas socialbidragsmottagande ur ett invandringspolitiskt perspektiv. Genom att följa invandrargruppernas socialbidragstagande kan en aspekt av integrationsprocessen belysas.

Men för att kunna ge en god bild av in- vandrarnas socialbidragstagande är det nödvändigt att följa invandrarbefolkningen under en följd av år. Eftersom invandrarbefolkningen i sig är en mycket heterogen befolkningsgrupp är det först och främst av intresse att försöka belysa hur olika grupper av invandrare förhåller sig till varandra. Invandrargruppen skiljer sig dessutom i förhållande till de infödda utefter ett flertal dimensioner. Dessa aspekter är också nödvändiga att beakta när invandrarbefolkningen jämförs med den infödda befolkningen.

Den här studien baseras på ett rikstäckande datamaterial. Det empiriska materialet har dessutom den fördelen att det utgår från personernas födelseland istället för medborgarskap. Det möjliggör, till skillnad från den officiella socialbidragsstatistiken, att personernas bidragstagande kan följas oberoende av om personen naturaliseras ${ }^{1}$ eller ej. Dessutom sträcker sig observationstiden över tio års perioden 1983-92, vilket medför att återkommande tvärsnittsanalyser låter sig göras. Datamaterialet möjliggör således att invandrares socialbidragsberoende kan belysas ur ett longitudinellt perspektiv men det bör uppmärksammas att perioden som studeras är tiden innan arbetsmarknaden dramatiskt försämrades. Genom att det empiriska materialet dessutom innehåller information om invandringsår kan bidragstagare med olika vistelsetid i landet studeras. Det är först

1 Naturalisering, dvs. när personen får svenskt medborgarskap. Invandraren kan ansöka om svenskt medborgarskap efter fyra alternativt fem års bosättning i Sverige beroende på vilka grunder bosättningstillstånd har beviljats. 
med den här samlade informationen som invandrares socialbidragstagande kan belysas.

I och med denna studie presenteras nu kunskap om invandrarnas socialbidragstagande i Sverige. Ambitionen med den här artikeln är främst att besvara två frågor: hur snabbt invandrarna tar sig ur socialbidragstagandet med ökad tid i det nya landet samt om olika grupper av invandrare har olika svårt att ta sig ur socialbidragsberoendet?

Artikel inleds med en beskrivning av invandrares speciella situation som nyanlända till landet samt hur invandrargruppen förhåller sig till de infödda vad gäller ett antal faktorer såsom arbetsmarknad, utbildning, ålder mm. Därefter beskrivs socialbidragets utbredning bland befolkningen samt olika gruppers ackumulerade erfarenhet av socialbidrag. Även socialbidragets tidsmönster bland olika grupper studeras. Slutligen beskrivs invandrares socialbidragsmottagande utifrån hur det påverkas av vistelsetiden $\mathrm{i}$ landet.

\section{Invandrare på arbetsmarknaden och $\mathbf{i}$ socialförsäkringen}

\section{Invandringsförloppet}

För att belysa invandrargruppernas socialbidragstagande är det nödvändigt med en bakgrundsbeskrivning dels av invandrargruppernas arbetsmarknadssituation, dels av hur konstruktionen av olika socialförsäkringar samt hur förändringar i dessa, direkt påverkar invandrargruppernas bidragsmottagande. En kortfattad beskriv- ning av invandrarens specifika position som nyanländ till landet anses också som väsentlig för förståelsen av invandraren som socialbidragstagare.

Till att börja med bör hållas i minnet att invandrarbefolkningen är en mycket heterogen grupp och att det enda som egentligen förenar dem är att de är födda utom Sverige. De har olika utbildning, erfarenheter, språkkunskaper, vistelsetid i Sverige etc. Den utländskt födda befolkningen har olika skäl till varför man valt att bosätta sig i Sverige. Ungefär en tredjedel av dagens invandrare brukar betraktas som arbetskraftsinvandrare och en lika stor grupp har kommit till Sverige av flyktingskäl. Den återstående tredjedelen av de utländskt födda har fått uppehållstillstånd genom att de är anhöriga till någon som invandrat till Sverige eller till någon svensk.

Det förefaller rimligt att anta att motivet till att lämna sitt hemland påverkar personens integrationsprocess. Ett självvalt beslut att migrera är ofta ett resultat av en längre tids övervägande där fördelarna med flyttningen överväger. Flyktingar lämnar ofta sitt hemland efter ett beslut om migration som grundar sig på helt andra överväganden. Att flyktingars migrationsbeslut avgörs av yttre omständigheter, och i mindre grad som ett individuellt beslut, är faktorer som med stor sannolikhet påverkar integrationsprocessen.

Vid ankomsten till ett nytt land förlorar migranten en del av det humankapital han har förvärvat i hemlandet. Många kunskaper och erfarenheter från hemlandet är svåra att överföra och accepteras inte heller alltid av mottagarlandet. För invandrare som kommer från ett land som är geogra- 
fiskt näraliggande Sverige finns stora möjligheter att överföra kunskaper och erfarenheter till den nya situationen de befinner sig i. I många fall är språket inte helt främmande och utbildningen från hemlandet kan relativt lätt jämföras med svenska utbildningar. Migranter som har sitt ursprung i länder som för svenskar är relativt okända och främmande genomgår sannolikt en betydligt längre och svårare process innan de erfar samma acceptans. Vissa invandrare, oavsett ursprungsland, förlorar i större grad än andra sitt humankapital vid migrationen. I vad mån den enskildes utbildning och erfarenhet är överförbar till förhållanden i Sverige eller om dessa bygger på lokala förhållanden avgör hur stor förlust personen gör vid byte av arbetsmarknad.

I takt med vistelsetiden i det nya landet skaffar sig invandrarna det humankapital som behövs för att konkurrera på den nya arbetsmarknaden. Språkliga färdigheter samt nya erfarenheter och eventuellt ny utbildning införlivas efter hand. Antalet nya kontakter är dessutom med all sannolikhet en mycket viktig faktor. Dels är antalet kontaktytor med de infödda viktigt, dels är kontakterna med egna landsmän avgörande för integrationen. Troligtvis innebär detta att de första invandringsgrupperna från ett nytt ursprungsland möter större svårigheter än de som kommer därefter.

Allt eftersom andelen utrikes födda personer ökar tenderar familjebildning över etniska gränser att bli allt vanligare (Folk- och bostadsräkning 1990). En sådan familjemässig integrering antas också ha en positiv effekt för invandrarens integrering i det nya landet (Gustafsson 1997).

\section{Invandrare och arbetsmarknad} Eftersom socialbidragstagandet ofta är en direkt spegling av sysselsättningssituationen kan det vara lämpligt med en beskrivning av invandrarnas situation på arbetsmarknaden i förhållande till de inföddas. Förutom att den enskilde genom arbetet erhåller sin försörjning ger arbetet också tillgång till viktiga delar av socialförsäkringssystemet.

Det finns en omfattande empirisk forskningslitteratur om invandrarnas situation på arbetsmarknaden (Gustafsson, Zamanian \& Aguilar 1990, Ekberg \& Andersson 1995, Ekberg \& Gustafsson 1995, Gustafsson 1997) enligt vilken en stor roll spelas av hur länge man har varit i det nya landet. Invandrarnas sysselsättningsläge var god fram till mitten av 70-talet. Därefter har invandrarnas situation försämrats både vad gäller förvärvsfrekvens och arbetslöshet. Invandrarna är, i förhållande till ursprungsbefolkningen, i hög grad sysselsatta inom tillverkningsindustrin och de drabbades hårt av konjunkturnedgången $\mathrm{i}$ slutet på 70-talet.Trots att efterfrågan på arbetskraft steg under 80-talet har sysselsättningsgraden för dessa grupper fortsatt att minska. Denna trend har förstärkts under 90-talet.

Det råder framför allt stora skillnader i arbetsmarknadsläge mellan olika grupper av invandrare. Arbetsmarknadssituationen har varit relativt gynnsam för de s.k. arbetskraftsinvandrarna, dvs. de som kom till Sverige under 60- och 70-talet (Ekberg 1983). Deras socioekonomiska karriär och inkomstutveckling har varit ungefär densamma som för de svenskfödda. Invandrarna hade till och med högre sysselsättnings- 
grad än den infödda befolkningen. Trots att många av invandrarna hade låginkomstyrken så lyckades de, genom långa årsarbetstider samt att de utländska kvinnorna i större grad än svenska kvinnor arbetade heltid, nå högre arbetsinkomster än infödda personer. Samma utveckling gäller även dåtidens flyktingar vilka till största delen kom från Östeuropa. Den gynnsamma situationen för invandrarna började vända redan i mitten av 70-talet. Framför allt har dessa tidigare invandrare drabbats härt av lågkonjunkturen under 90-talet (Arbetsmarknadsdepartementet 1990, Invandrarpolitiska kommittén 1996, Statens invandrarverk 1997).

De största svårigheterna hittar man dock bland invandrare som kommit till landet under 80- och 90-talet. Förutom en mycket låg sysselsättningsgrad har denna grupp även drabbats hårt av arbetslösheten. De har haft svårt att etablera sig på arbetsmarknaden och många av dem som väl fått arbeten har hamnat i yrken som ligger under deras formella utbildningsnivå. Framför allt har de utomeuropeiska invandrarna drabbats hårt. En betydande del av dessa är flyktingar och det kan vara rimligt att anta att integrationen för flyktingar och invandrare från kulturellt avlägsna platser tar relativt längre tid. Utvecklingen pekar dock på att sysselsättningsgraden är låg och arbetslösheten hög för denna grupp även efter en lång tid i landet (Ekberg \& Andersson 1995). Bland de utomeuropéer som anlände 1980-90 var sysselsättningsgraden för män mindre än hälften av de infödda männens. Motsvarande för kvinnor var bara en tredjedel av den för infödda kvinnor. Enligt arbetskraftsundersökning- en 1995 är den öppna arbetslösheten mer än tre gånger större bland utländska medborgare än bland svenska medborgare. När det gäller invandrare från utomeuropeiska länder är arbetslösheten fyra gånger så stor som för svenska medborgare. Även de grupper som invandrat före 1970 är numera mindre ekonomiskt integrerade än vad de tidigare var. Det innebär att en längre tid i landet inte nödvändigtvis behöver innebära att arbetsmarknadssituationen förbättras.

\section{Invandrare och socialförsäkringar}

Socialförsäkringarnas syfte är att skydda individer som har svårt att försörja sig på grund av sjukdom, arbetslöshet, arbetsskada, ålderdom, vård av barn eller helt enkelt för att personen har för låga inkomster $i$ förhållande till försörjningsbördan. Det offentliga utbudet av ersättningar som utgår till individen varierar i de allra flesta fall utifrån nivån på den försäkrades arbetsinkomster. Dessutom är det för vissa förmåner en förutsättning att en förlust av arbetsinkomst föreligger för att ersättning över huvud taget ska utbetalas. Det betyder att personer som inte har etablerat sig på arbetsmarknaden inte har samma möjligheter att få ersättningar i de fall han behöver ha ekonomiskt stöd till sin försörjning. Invandrarna är i högre grad än övriga personer i befolkningen utan helt socialförsäkringsskydd (Socialstyrelsen 1995b). För de personer som av en eller annan anledning saknar skydd i form av olika socialförsäkringsförmåner återstår socialbidraget som ett sista försörjningsstöd.

Invandrare som inte står till arbetsmark- 
nadens förfogandet, t.ex. på grund av sjukdom, ålderdom eller vård av barn är helt och hållet hänvisade till socialbidragsförsörjning. För rätt till full folkpension krävs t.ex. numera att personen varit bosatt $\mathrm{i}$ landet i 40 år. Följaktligen innebär det att så gott som ingen av dagens nyblivna förstagenerationsinvandrare lyckas bli berättigade till full folkpension.

Hälsotillståndet och sjukvårdskonsumtionen skiljer sig dessutom i väsentliga delar mellan invandrare och infödda svenskar. Orsakerna till detta kan till stor del förklaras av skillnader i köns- , ålders- och klasstruktur samt familjeförhållanden (Hjern 1995, Soydan 1995, Riksförsäkringsverket 1996, Statens invandrarverk 1997).

\section{Invandrares rätt till socialbidrag}

De institutionella ramarna sätter gränser för vem som har rätt till ekonomisk hjälp. I Sverige har samtliga personer som har rätt att vistas i landet också möjlighet att få socialbidrag till sitt uppehälle. Denna möjlighet för asylsökande och invandrare är långt ifrån den samma $i$ alla västeuropeiska länder (Eardley et al 1996). Den svenska modellen bygger på det s.k. jämlikhetsmålet, dvs. att invandrare ska ha samma rättigheter och skyldigheter som infödda. Rättigheten till socialbidrag har varierat från tid till annan för invandrarbefolkningen men den ger idag en invandrare omedelbar rätt att ansöka om socialbidrag efter det att bosättningstillstånd erhållits.

När en person kommer till Sverige som asylsökande och saknar egna medel att försörja sig utbetalas asylbidrag fram tills beslut om rätt till bosättning föreligger eller ej. Först efter att den enskilde har uppehållstillstånd $i$ landet har han rätt till socialbidrag. Socialbidraget används sedan 1985 även som försörjningsstöd under en introduktionsperiod för nyanlända invandrare. Under introduktionsperioden, som till största delen består av svenskundervisning, kan även s.k. introduktionsbidrag utges. Detta bidrag infördes först 1993 och gav kommunerna en större möjlighet att påverka nivån och utformningen av bidraget än vad socialbidraget innebar. ${ }^{2}$

En rad olika administrativa system har gällt under de senaste decennierna vid mottagandet av asylsökande och flyktingar. Efter det att flyktingmottagandet överfördes från Arbetsmarknadsstyrelsen till Statens invandrarverk 1985 gavs försörjningsskyddet för både asylsökande och flyktingar via kommunernas socialbidragshantering. Tre år senare infördes lagen om bistånd åt asylsökande som innebar att de asylsökande lyftes ut ur socialbidragshanteringen för att istället erhålla ett speciellt asylbidrag. ${ }^{3}$ Detta bidrag är som regel lägre än socialbidragsnormen.

Ett antal administrativa förändringar under de senaste decennierna har också skett vad gäller hur, och till vilken grad, staten ersätter kommunerna för de kostnader som uppkommer i samband med mottagandet av flyktingar. Mellan 1985 och

2 I de fall som kommuner har infört introduktionsersättning redovisas detta som socialbidragsutbetalningar.

3 Genom att asylbidraget infördes och att de asylsökande därmed exkluderades från socialbidragsstatistiken medför detta problem vid jämförelser av socialbidrag före och efter förändringen. 
1991 ersatte staten kommunerna fullt ut för de socialbidragskostnader som uppkom för flyktingar. 1991 ändrades ersättningssystemet till en s.k. schablonersättning vilket innebär att kommunerna får en bestämd ersättning för varje mottagen flykting. Det statliga bidraget till kommunerna avser att schablonmässigt täcka de kostnader som kommunen har för nyanlända flyktingar mottagningsåret samt ytterligare tre år. ${ }^{4}$ Flyktingarna förväntas därefter vara integrerade..$^{5}$ En intressant fråga att undersöka är hur lång tid det tar för olika invandrargrupperna att bli ekonomiskt integrerade. I Invandrarpolitiska kommitténs förslag (SOU 1996:55) ska säråtgärder för invandrare begränsas till fem år. Därefter sägs de endast omfattas av de generella välfärdspolitiska medlen. I den här studien

4 Huruvida den statliga ersättningen täcker de kostnader som kommunerna har för flyktingmottagandet är en pågående diskussion mellan kommun och stat. Ur Inrikesdepartementets (Ds 1997:31) uppföljning av 1992 års mottagna flyktingar framkommer att 41 procent av de undersökta kommunerna har fått sina kostnader täckta genom den statliga ersättningen. Individuppföljningen i samma undersökning visar att 6 procent av 1992 års flyktingar hade egen försörjning i form av löneinkomst efter att de varit bosatta i genomsnitt 3,5 år i Sverige.

5 Integrationsbegreppet har varit en återkommande diskussionsfråga. Det råder en viss begreppsförvirring när det gäller begreppet integration (Diaz 1993). Integrationsprocessen är komplex och låter sig inte beskrivas med enkla mått utan kräver en belysning av ett antal dimensioner. En av dessa dimensioner kan vara ekonomisk integration. Oftast menas då invandrarnas inlemmande $i$ arbetslivet. finns det möjlighet till återkomma till frågan i vilken takt invandrare ekonomiskt integreras in i egenförsörjning.

\section{Invandrarbefolkningens flerdimensionalitet}

Invandrare är en beteckning för en mycket heterogen kategori av befolkningen. Invandrarnas ålderssammansättning är annorlunda än i den infödda befolkningen (SCB 1995). Jämfört med svenskarna är en större andel av invandrarna i förvärvsaktiv ålder. Men det förekommer stora variationer inom invandrargruppen. Förutom att invandrarna har kommit till Sverige från olika länder under olika tidsperioder, varierar ålder och vistelsetid mellan invandrare av olika ursprung. Många av dagens nordiska invandrare är medelålders och har varit bosatta i Sverige under relativt lång tid. Invandrare som kommer från typiska flyktingområden, t.ex. Asien, Afrika och Latinamerika, är oftare yngre personer. De har varit bosatta i Sverige en kort period och kan även med hänsyn till åldern sägas befinna sig i början av sin yrkesaktiva period.

Invandrarbefolkningen är också geografiskt annorlunda fördelad än den infödda befolkningen. Invandrarna är starkt koncentrerade till storstadsområdena och de har dessutom en hög intern omflyttning inom landet jämfört med infödda i samma ålder. Ungefär hälften av alla utrikes födda i arbetsför ålder bor i Stockholms-, Göteborgs- respektive Malmö regionen. Inom de regioner som har störst andel invandrare är dessa dessutom starkt koncentrerade till vissa bostadsområden. Vad gäller flyttningsrörelser skiljer sig dessa mellan olika

Eva Franzén: Invandrare och socialbidrag 
invandrare. Personer som är nya i landet har större flyttningsbenägenhet. Detta gäller även yngre personer.

Även utbildningsnivån varierar bland de utrikes födda. Generellt sett är dock utbildningsnivån jämförbar med de svenskföddas. Det finns däremot stora skillnader inom invandrargrupperna, beroende på vilket land de kommer ifrån och vilka skäl som ligger bakom migrationen. Skillnader i utbildningsnivå mellan infödda svenskar och olika invandrargrupper sammanhänger inte bara med nationell och social bakgrund utan också med gruppernas olika ålderssammansättning.

\section{Att studera invandrare $\mathrm{i}$ socialbidragssystemet}

Trots diskrepanser mellan olika nationers bidragssystem kan en blick på utlandet vara på sin plats. Intressant är att försöka skönja om dynamiken i bidragsmönstren är densamma som den som framkommer i svenska studier. Studier som i det här sammanhanget är värda att uppmärksamma och som också bygger på stora databaser och kvantitativa metoder är framför allt Jensen (1988), Borjas \& Trejo (1991) samt Borjas $(1995,1996)$. De har studerat invandrarnas andel av socialbidragstagandet i USA och hur olika nationella gruppers bidragsberoende ser ut i jämförelse med den infödda befolkningens. Resultaten bygger på tvärsnittsanalyser från tre olika folkräkningar. De pekar på att invandrare i USA assimileras in i socialbidragssystemet. Det innebär att ju längre en invandrare är bosatt $i$ landet desto mer sannolikt är det att han kommer att bli bidragsberoende. En förklaring till detta som Borjas framhåller är att invandrare i USA eventuellt fruktar repressalier i form av deportation eller att möjligheten till medborgarskap skulle påverkas vid bidragsutnyttjande. Bidragsmottagandet visar sig variera mellan olika grupper av invandrare. Detta sammanfaller å andra sidan med de olika invandrargruppernas olika vistelsetid i landet. Studierna visar att flyktinghushåll är i betydligt högre grad bidragsmottagare än andra invandrargrupper. Även när flyktinghushållen har varit bosatta i landet i 20 år är deras bidragsmottagande högre än för både infödda och andra invandrargrupper. ${ }^{6}$

Liknande resultat framkommer ur Bakers \& Benjamins (1994) kanadensiska analyser av invandrares socialbidragstagande. Även här assimileras invandrarna in i socialbidragssystemet, dvs. invandrarna har ett lågt bidragsberoende vid ankomsten till landet men längre tid $i$ landet innebär ett allt högre bidragstagande.

Resultat från ett mer närliggande område är två undersökningar från Norge (Blom 1996, Vassenden 1997) där socialbidragsmottagandet bland flyktingar och invandrare studeras. I dessa framskymtar andra mönster än vad som presenterats ovan. I Norge sjunker andelen bidragsmottagare i takt med att vistelsetiden i landet ökar. Dock tenderar nya invandringsgrupper att generellt sett ha en något högre andel bidragsmottagare än sina föregångare.

Med dessa utländska studier i minnet

6 Till viss del kan detta förklaras av att flyktingar i USA har tillträde till fler sociala förmåner än andra invandrargrupper samt att andelen flyktingar har ökat. 
övergår vi nu till socialbidragsmottagandet i Sverige och hur detta ser ut med avseende på om mottagaren är född inom eller utom riket.

\section{Forskningsstrategi}

Den svenska socialbidragsforskningen har länge dominerats av tvärsnittsstudier. Socialbidragstagarnas bidragsmönster har därmed svårligen kunnat tolkas och det rådde länge en föreställning om att socialbidragstagaren var en person med långvarigt eller permanent behov av hjälp. Bane \& Ellwood (1986) utvecklade den amerikanska fattigdomsforskningen genom att beskriva dynamiken i fattigdomen men också i socialbidragstagandet. Grunden för att studera detta är att följa bidragsmottagarna över en följd av år. Först med hjälp av en longitudinell forskningsansats kan mönster i bidragsmottagandet utkristalliseras. Salonen (1993) har på ett väsentligt sätt bidragit till att den svenska kunskapen om socialbidragsmottagandet har ökat. Genom att han använder ett longitudinellt perspektiv när han undersöker fyra skånska kommuner framkommer bland annat att socialbidraget är en betydligt mer vanlig bidragsform än vad traditionella tvärsnittsstudier kan ge intryck av samt att de allra flesta hushåll erhåller socialbidrag endast högst tillfälligt.

Ambitionen med den här artikeln är att jämföra hur invandrarhushållens socialbidragstagande med de svenskföddas samt belysa hur bidragsberoendet ser ut med avseende på olika ursprungsländer. Fördelen med denna studie är att ett longitudinellt perspektiv kan utnyttjas, dvs. bidragstagarna kan följas över tiden. Redovisningen av materialet kommer att ske med utgångspunkt från tre centrala begrepp; erfarenhet, kontinuitet samt kohort. Med hjälp av dessa begrepp kommer jag att belysa socialbidragets utbredning $\mathrm{i}$ befolkningen samt hur varaktigheten i socialbidragsmottagandet ser ur i förhållande till olika befokningsgrupper. Till sist kommer olika kohorters, dvs. olika årgångar av invandrare, socialbidragstagande att belysas för att studera betydelsen av vistelsetiden $\mathrm{i}$ Sverige.

I följande redovisning kommer jag att använda mig av upprepade tvärsnittsanalyser. Eftersom invandrarnas socialbidragmottagande är starkt kopplat till vistelsetiden i landet kommer bidragsmottagandet belysas utefter olika invandringskohorter. Förutom att studera olika invandrargruppers socialbidragsandelar i respektive befolkningsgrupp kommer även den ackumulerade erfarenheten av socialbidrag att belysas. Den ackumulerade erfarenheten av socialbidrag ger oss kunskap om socialbidragets utbredning i befolkningen. Genom att datamaterialet ger möjlighet att belysa detta ur en tioårsperiod kan vi få en bild av socialbidragserfarenheten bland olika befolkningsgrupper.

Det empiriska materialets panelkaraktär kommer här att användas genom att enskilda socialbidragshushåll följs under observationsperioden. Detta bidrar till att belysa varaktigheten av beroendet för olika grupper av bidragsmottagare. Det finns stora möjligheter att i fortsatta studier fördjupa analyserna av socialbidragsdynamiken genom att använda datamaterialets panelkaraktär och möjligheter till multivariata analyser. Denna artikel ska därmed ses 
som starten på en fördjupning av kunskapen om invandrarnas socialbidragstagande.

\section{Datamaterialet}

Datamaterialet bygger på två stickprov ur SCB:s register över totalbefolkningen. För att fånga dynamiken och variationsrikedomen bland bidragsmottagarna används här ett tioårsperspektiv, 1983-92. Materialen består av 1 procent av den svenskfödda befolkningen och 10 procent av den utrikes födda. Datamaterialet har varje år kompletterats med 10 procent av nyanlända utrikes födda. Urvalspersonerna har länkats samman med sambeskattade personer. Tack vare detta.är. det möjligt att skapa hushåll, vilket är nödvändigt för att kunna studera socialbidragsmottagandet. Socialbidraget utbetalas visserligen till en personen i hushållet men är för den skull inget individuellt bidrag utan avser att täcka hela familjens behov. Studier av socialbidrag utgår därför från hushållsnivå. ${ }^{7}$

När hushåll har bildats utifrån urvalspersoner som är över 18 år framkommer att stickproven består av i genomsnitt av 70000 svenskfödda hushåll samt respektive 60000 utländskt födda hushåll per år. Socialbidragsmottagandet studeras för den vuxna befolkningen. I de fall hushållen består av

7 Materialet tillăter endast en smal definition av hushåll, dvs. hushållen bildas utefter taxeringsuppgifter vilket innebär att en hushållsenhet är ensamstående, gifta par eller sammanboende med minderåriga barn. Det innebär att sammanboende utan minderåriga barn betraktas som två enskilda hushåll. Förändringar av hushållssammansättningen under ett enskilt år beaktas ej. personer med olika ursprungsländer har mannens födelseland beslutats vara avgörande. Datamaterialet innehåller förutom personuppgifter, ursprungsland, migrationsår och medborgarskap även uppgifter om inkomster och transfereringar.

Detta empiriska material bygger, till skillnad från andra undersökningar, på personens födelseland. Länderna har därefter grupperats efter dels hur de förhåller sig till varandra på kartan, dels om de är ett s.k. flyktingproducerande land eller ej. ${ }^{8}$ Detta innebär visst metodproblem då det inte klart framgår orsaker till varför personen invandrat till Sverige. Det förekommer att personer från samma land och under samma period har sökt sig till Sverige av

8 Norden (Danmark, Finland, Norge)

Västeuropa m.fl. (Tyskland, Schweiz, Österrike, Frankrike, Belgien, Holland, USA, Kanada, Australien, Nya Zeeland)

Östeuropa (Polen, Ungern, Albanien, Bulgarien, Rumänien, Tjeckoslovakien, Sovjet inklusive de baltiska staterna)

Sydeuropa (Grekland, Jugoslavien, Andorra, Malta, Portugal, San Marino, Spanien, Vatikanstaten)

Mellanöstern och Nordafrika (Algeriet, Egypten, Djibouti, Libyen, Marocko, Tunisien, Förenade arabemiraten, Jemen, Jordanien, Kuwait, Libanon, Oman, Qatar, Saudi arabien, Sydjemen, Syrien, Irak, Iran, Turkiet) Övriga världen (Etiopien, Sub-Sahara, Latinamerika, Övriga Asien, Oceanien, statslösa) Flyktingland (Grekland, Polen, Ungern, Östeuropa, Etiopien, Chile, Irak, Iran, Turkiet, Sovjet)

Icke flyktingland (Danmark, Finland, Norge, Jugoslavien, Tyskland, Sydeuropa, Västeuropa, Arabländerna, Sub-Sahara, Latinamerika, Kanada, Australien, Nya Zeeland, Övriga Asien, Oceanien) 
Figur 1 Andelen socialbidragshushaill inom respektive grupp

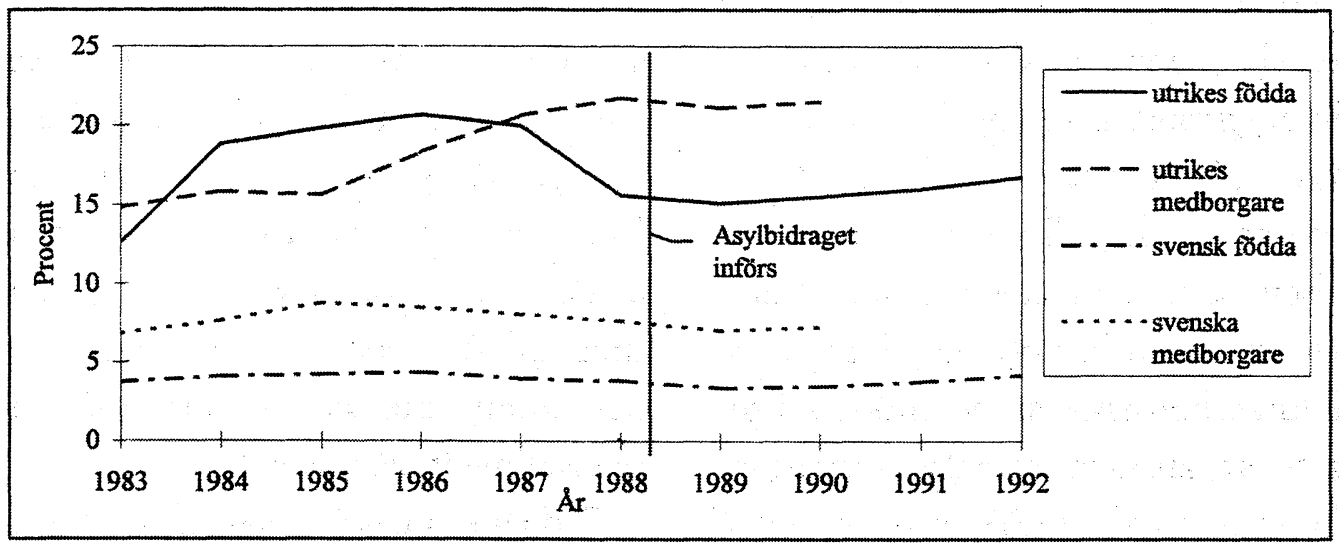

Figur 1: Andelen socialbidragshushåll inom respektive grupp.

flyktingskäl eller av andra skäl. Ett sådant exempel är Grekland som i denna analys kommer att behandlas som ett flyktingland. Detsamma gäller Turkiet. ${ }^{9}$

\section{Jämförelse mellan svenskar och utrikes födda}

Den officiella socialbidragsstatistiken utgår från personernas medborgarskap. Men medborgarskapet är kopplat till vistelsetiden i Sverige. Ungefär 50 procent av samtliga invandrare erhåller svenskt medborgarskap efter några år i landet. Man kan anta att dessa har en bättre socioekonomisk situation än dem som inte har hunnit bli svenska medborgare. Analyser som utgår från medborgarskapet försvåras dessutom av att viljan till att byta medborgarskap skiftar bland olika grupper av invandrare. Man kan tänka sig att faktorer som t.ex.

9 Personer från före detta Jugoslavien kommer här uteslutande att betraktas som från ett icke flyktingland eftersom de flyktingar som kommit till Sverige i samband med kriget i Jugoslavien fick uppehållstillstånd först efter 1992, alltså är utanför denna studies observationstid. motivet till migrationen påverkar viljan till att byta medborgarskap. Personer som har flytt från sitt hemland kan antas ha större benägenhet att byta medborgarskap än vad andra invandrare har.

Sedan ett antal år tillbaka pekar den officiella statistiken på en dramatisk ökning av socialbidrag bland den utländska befolkningsgruppen. Under 1995 gick hälften av den utbetalade bidragssumman till de utländska hushållen. En stor del av dessa kostnader kan hänföras till introduktionsperioden för flyktingar. Bidragsbeloppet per utländskt bidragshushåll var dessutom dubbelt så stort som för svenskar, vilket förklaras dels av längre bidragstid, dels av att de utländska bidragshushållen oftare består av större familjer (Socialtjänst statistik 1997:1).

Som första resultat kan vi i det empiriska materialets tidsserier utläsa i figur $1 \mathrm{att}$ andelen svenskföddas socialbidragsberoende varit relativt konstant under tioårsperioden. Detsamma gäller för svenska medborgare, dvs. infödda och naturaliserade svenskar. Vår skattning är att i genomsnitt har 3,80 procent av de infödda vuxna 
någon gång under ett kalenderår mottagit socialbidrag. Utgår vi istället från de som har svenskt medborgarskap så är andelen socialbidragsmottagare ungefär dubbelt så hög, dvs. 7,68 procent.

Studerar vi socialbidragsmottagandet bland dem som är utrikes födda så framkommer att dessa har ett betydligt högre socialbidragsberoende än de infödda. I genomsnitt är andelen socialbidragstagare bland utrikes födda 17,08 procent, alltså fyra gånger högre än för de svenskfödda. Detta visar å andra sidan att de allra flesta, dvs. fem sjättedelar av de utländskt födda inte mottar socialbidrag.

Förändringar över tiden kan till viss del härledas till administrativa orsaker. Under 80-talets mitt nådde andelen utrikes födda sin kulmen vilket troligtvis kan förklaras av att socialbidrag då även utbetalades till asylsökande. I och med att det s.k. asylbidraget infördes 1988 minskade följaktligen socialbidragsutbetalningarna till de utrikes födda. Under 1992, som är tidsseriens sista år, skönjas åter en ökning av socialbidraget för de utrikes födda, vilket med all sannolikhet kan förklaras av strukturella faktorer i arbetslösheten spår, men också på grund av en stor flyktingmottagning.

Utrikes medborgare är i hög grad social- bidragsmottagare. 1990 var 21,51 procent av de utländska medborgarna mottagare av socialbidrag. Andelen utrikes medborgare med socialbidrag under samma år är alltså sex gånger högre än för de svenskfödda. Detta skall ses mot bakgrund av att många av de utrikes födda som mottog socialbidrag till stor del är nykomlingar i landet och ännu inte har kvalificerat sig för svenskt medborgarskap.

Tidigare socialbidragsstudier visar att socialbidragets åldersprofil har ändrat karaktär. Under tidigare decennier ökade risken för att behöva motta socialbidrag med stigande ålder. Under främst 80- och 90-talet har detta förändrats till det motsatta, dvs. att det är vanligast med socialbidrag $i$ de yngre åldersklasserna och att de äldres bidragsberoende minskar. Utbyggnaden av olika socialförsäkringsförmåner har medfört att gamla människor allt mindre är beroende av socialbidrag för sin försörjning.

Tabell 1 visar att socialbidrag är vanligt bland yngre, både för svenskfödda och utrikes födda. Både vad gäller de yngre och de medelålders är socialbidrag tre gånger vanligare bland utländskt födda än bland de infödda. Då vi vet att åldersstrukturen bland de utrikes födda är annorlunda än för den infödda befolkningen så framkom-

\section{Tabell 1}

Åldersspecifikt socialbidragstagande för infödda respektive utrikes födda

\begin{tabular}{lrrr} 
Årsgenomsnitt för perioden 1983-92 & 18-30 år & $31-50$ år & 61 år och äldre \\
\hline svenskfödd (antal bidragshushåll) & 118800 & 144200 & 16100 \\
utrikes födda (antal bidragshushåll) & 31610 & 51160 & 6860 \\
svenskfödd (andel bidragshushåll av inrikes födda) procent & 7,77 & 4,07 & 0,76 \\
utrikes född (andel bidragshushåll av utrikes födda) procent & 23,80 & 14,12 & 6,42 \\
svenskfödd (andel av totala antalet bidragshushåll) procent & 78,98 & 73,81 & 70,12 \\
utikes född (andel av totala antalet bidragshushåll) procent & 21,02 & 26,19 & 29,88
\end{tabular}


mer en något annorlunda bild av de utrikes födda socialbidragsmottagarna om vi konstanthåller för åldern. Här ser vi att överrisken att vara bidragsmottagare bland de utrikes födda sjunker, från fyra gånger högre än för de infödda, till tre gånger vid åldersspecifika analyser.

Att motta socialbidrag är mycket sällsynt bland äldre svenskfödda personer. Äldre personer som är födda utom riket har däremot i betydligt högre grad socialbidrag. En förklaring till detta är, som påpekats tidigare, att dessa personer inte i samma utsträckning har tillgång till pension. Materialet visar också genom att studera socialbidragets relativa andel av den disponibla inkomsten ${ }^{10}$ kan vi dessutom få en uppfattning om i vilken grad hushållen är beroende av socialbidrag. Som framgår av materialet förtydligas socialbidragets betydelse för den äldre åldersgruppen då socialbidragets andel av den disponibla inkomsten studeras. För de äldre utrikes födda består socialbidragsandelen av över 60 procent av den totala inkomsten medan det för den äldre svenskfödda befolkningen endast står för 10 procent.

Invandringen var stor i början av 90-talet och 1992 var ungefär 10 procent av samtliga invånare födda utomlands. Den svenska befolkningsstrukturen har därmed dramatiskt förändrats under de senaste decennierna. Det är därför intressant att försöka belysa socialbidragsmottagandet då även hänsyn tas till denna befolknings-

10 Den disponibla inkomsten är detsamma som hushållets totala inkomster, dvs. arbetsinkomster, kapitalinkomster och transfereringar minus skatt. förändring. Ett försök till en sådan beräkning blir möjlig om vi använder det empiriska materialet men tar hänsyn till att befolkningsstrukturen har förändrats under tiden. Under observationsperiodens tio år har sammansättningen av invandrarnas ursprungsländer förändrats. Från vissa länder ökar invandringen, från andra avstannar den. Man kan här ställa sig frågan om socialbidragstagandet proportionellt sett har ökat under observationstiden eller om socialbidragsökningen skett bland dem som är nyinvandrade till landet. En sådan fråga kan besvaras först om befolkningsstrukturen konstanthålls, dvs. då antalet i varje invandrargrupp är detsamma vid mättillfällets början och slut. Resultatet av en sådan beräkning visar att andelen socialbidragstagare bland de utrikes födda var 12,6 procent 1983 och att andelen ökade för samma befolkningsstruktur till 13,6 procent 1992. Härmed kan en relativt låg ökning av socialbidragstagandet konstateras. Troligtvis kan de ökade socialbidragskostnaderna istället tillskrivas de invandringsgrupper som är nyanlända i landet.

\section{Socialbidragserfarenhet}

Det är känt att en anmärkningsvärt stor del av befolkningen periodvis hänvisas till socialbidrag. Frågan gäller vilka grupper som berörs av socialbidrag och om det är samma personer som återkommer gång på gång eller om det sker en större genomströmning bland befolkningen. Salonen (1993) visar i sina studier från de fyra skånska kommunerna hur andelen personer som någon gång mottagit socialbidrag ökar allt eftersom antalet observationsår ökar. Det- 
ta gäller oavsett den ursprungliga andelen bidragshushåll. I Salonens studie visas att en betydande del av befolkningen erhållit socialbidrag vid åtminstone något tillfälle. Han uppskattar att var femte person i Sverige under en tioårsperiod har mottagit socialbidrag.

Resultatet av denna undersökning pekar i samma riktning. Av tabell 2 framgår att socialbidragets utbredning bland befolkningen är betydligt större än vad som man skulle kunna tro utifrån årliga tvärsnittsdata. Här görs, till skillnad från Salonens studie, dessutom en jämförelse mellan svenskfödda och utrikes födda. Resultaten här pekar mot att det är framför allt vanligt med socialbidrag bland de utländska hushållen. Under en tioårsperiod har en fjärdedel av de utrikes födda hushållen någon gång mottagit socialbidrag, medan cirka 10 procent av de svenskfödda hushållen har erfarenhet av socialbidrag under samma period. Detta visar mycket tydligt att socialbidraget långt ifrån riktar sig till en marginell grupp i samhället. Socialbidragser- farenheten är framförallt stor bland de utländskt födda personerna. Bland dessa får socialbidraget betraktas som ett vanligt förekommande bidrag.

Av figur 2 kan man se den ackumulerade bidragserfarenheten bland de utrikes födda från olika länderkategorier är mycket varierande. Lägg dock märke till att samtliga länderkategorier har högre bidragserfarenhet än svenskfödda. Bland personer från Mellanöstern m.fl. och s.k. övriga världen är det mycket vanligt med socialbidragserfarenhet. Här finner vi att över hälften av hushållen under en tioårsperiod någon gång mottagit socialbidrag. Troligtvis kan detta till stor del förklaras av att dessa grupper av invandrare ofta kommit till Sverige som flyktingar och att det då är naturligt att motta socialbidrag under introduktionsperioden i landet. Bland övriga, dvs. nordbor, väst-, öst- och sydeuropéer är bidragserfarenheten dubbelt så stor under tioårsperioden än vid en ettårsbetraktelse. Cirka 20 procent av dessa har varit mottagare av socialbidrag. Personer från Västeu-

\begin{tabular}{|c|c|c|c|}
\hline Ar & Antal år & Andel svenskfödda hushåll & Andel utrikesfödda hushåll \\
\hline-1983 & 1 & 3,41 & 11,52 \\
\hline 1983-84 & 2 & 5.04 & 15,77 \\
\hline 1983-85 & 3 & 6,30 & 18,53 \\
\hline 1983-86 & 4 & 7,27 & 20,41 \\
\hline 1983-87 & 5 & $7 ; 94$ & 21,61 \\
\hline 1983-88 & 6 & 8,55 & 22,59 \\
\hline 1983-89 & 7 & 9,01 & 23,47 \\
\hline 1983-90 & 8 & 9,48 & 24,24 \\
\hline |983-9| & 9 & 10,04 & 25,13 \\
\hline 1983-92. & 10 & 10,59 & 25,93 \\
\hline
\end{tabular}


Figur 2 Ackumulerad bidragserfarenhet

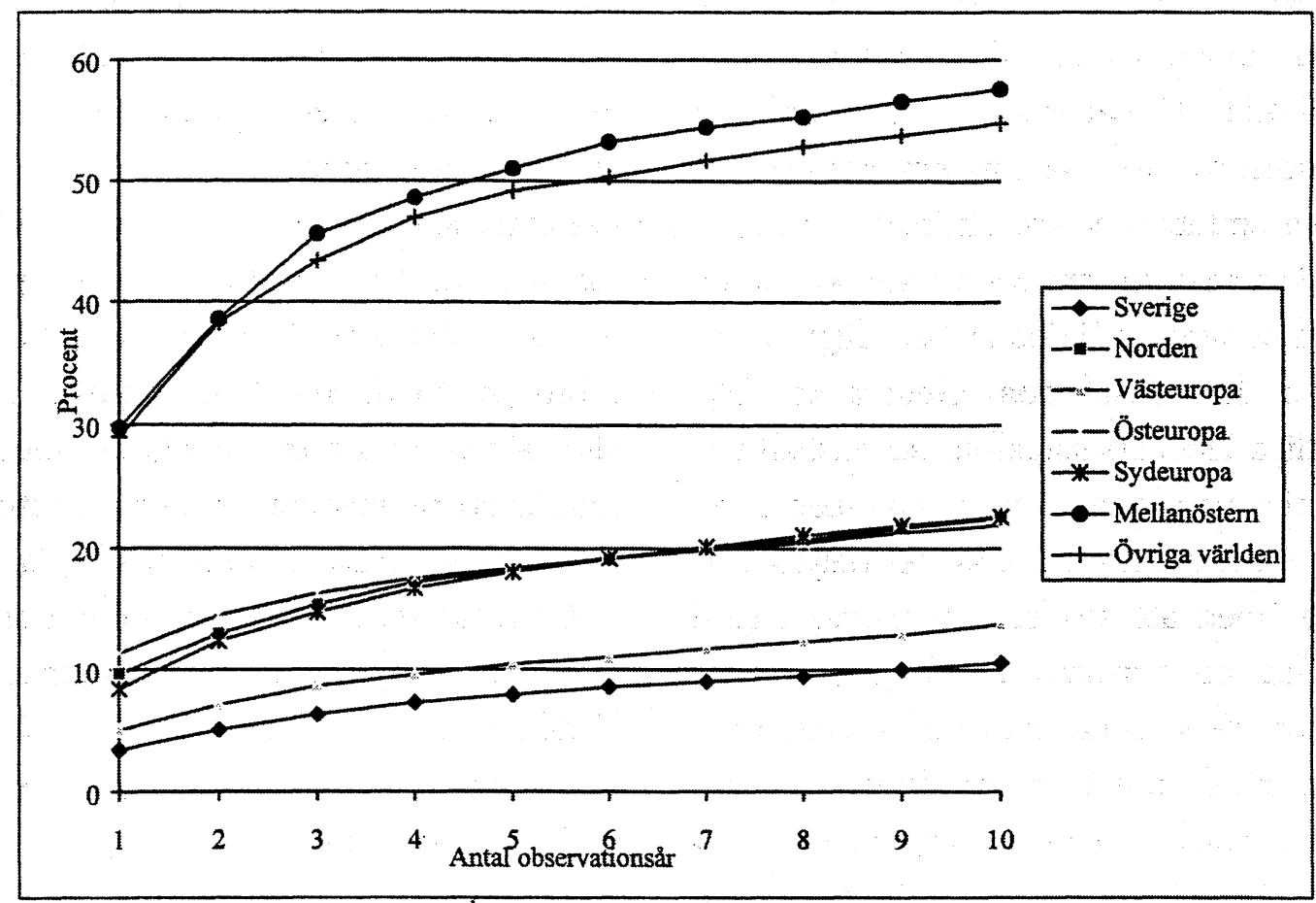

Figur 2: Ackumulerad bidragserfarenhet

ropa m.fl. har i något lägre grad, cirka 14 procent, erfarenhet av socialbidrag.

Det sker alltså en markant ökning av socialbidragets utbredning i befolkningen $\mathrm{i}$ takt med att observationstiden förlängs, oavsett den ursprungliga bidragsnivån vid tvärsnittsanalyser. Studeras den relativa ökningstakten framkommer att socialbidragsandelen i befolkningen fördubblas i så gott som samtliga av länderkategorierna under tioårsperioden. De svenska bidragshushållen tredubblades under samma period.

\section{Socialbidragets kontinuitet}

Att försöka studera socialbidragets varaktighet har visat sig vara komplicerat. Då det finns en enorm variationsrikedom i bidragstiderna krävs det att observationstiden utvidgas till en följd av år för att där- med kunna spegla verkligheten mer rättvist än vad årliga tvärsnittsdata gör. Här kommer vi att studera socialbidragets varaktighet på två sätt, dels utifrån om socialbidragsmottagandet är permanent, dvs. om bidragsmottagaren mottar socialbidrag varje år. Dels kan varaktigheten studeras oberoende av hur ofta personen återkommer som bidragstagare. Det är naturligt att dessa olika sätt att studera socialbidragets varaktighet också ger olika resultat. Det är däremot mer intressant hur detta förhåller sig mellan olika grupper av bidragsmottagare. Salonen (1993) visar i sina studier att rörligheten bland socialbidragsmottagandet är omfattande. I hans studie är hälften av hushållen aktuella under endast ett kalenderår. Majoriteten av dessa bidragshushåll hade endast tillfälliga bidragsbehov och för de flesta är socialbidraget en 
snabbt övergående bidragsform. Det finns därmed anledning att försöka studera om dessa slutsatser kan gälla även för de utrikes födda. Då många av de senare anlända invandrarna inte i samma omfattning som övriga omfattas av socialförsäkringssystemet kan man misstänka att varaktigheten bland de utrikes födda är betydligt längre än för de svenskfödda. Genom att följa samtliga 1983 års socialbidragshushåll under tioårsperioden kan dynamiken i bidragsmottagandet till viss del belysas. Vi börjar med att studera de bidragstagare som har ett permanent bidragsmottagande, dvs. de som har mottagit socialbidrag någon gång varje år under observationsperioden. Härmed kan rörligheten i bidragstagandet belysas. Intressant är att studera i vad mån socialbidragsdynamiken skiljer sig beroende på personens ursprung.

Figur 3 visar socialbidragets varaktighet. Här framgår tydligt att kurvorna inte skiljer sig nämnvärt åt för svenskfödda el- ler utrikes födda. Inte heller förekommer några skillnader i varaktighet beroende på om mottagaren kommer från ett traditionellt flyktingland eller från ett annat land. Tydligt framkommer att redan efter två år kvarstår bara 50 procent av dem som hade socialbidrag 1983. Vid observationsperiodens slut, dvs. efter tio år, får endast cirka 7 procent fortfarande socialbidrag. Detta visar alltså att det är ovanligt att socialbidrag är ett permanent försörjningsalternativ för både svensk- och utlandsfödda.

Datamaterialet tillåter ännu en uppdelning efter olika länder. Vid en sådan analys framkommer att personer födda i Mellanöstern har en något mindre sluttande kurva än vad som presenterades ovan. Dock visar den samma mönster som för övriga länderkategorier, dvs. att endast cirka 9 procent av 1983 års socialbidragstagare mottog bidrag permanent under en tioårs period. Till skillnad från vad man kunde förvänta sig efter utfallet av tvärsnittsana-

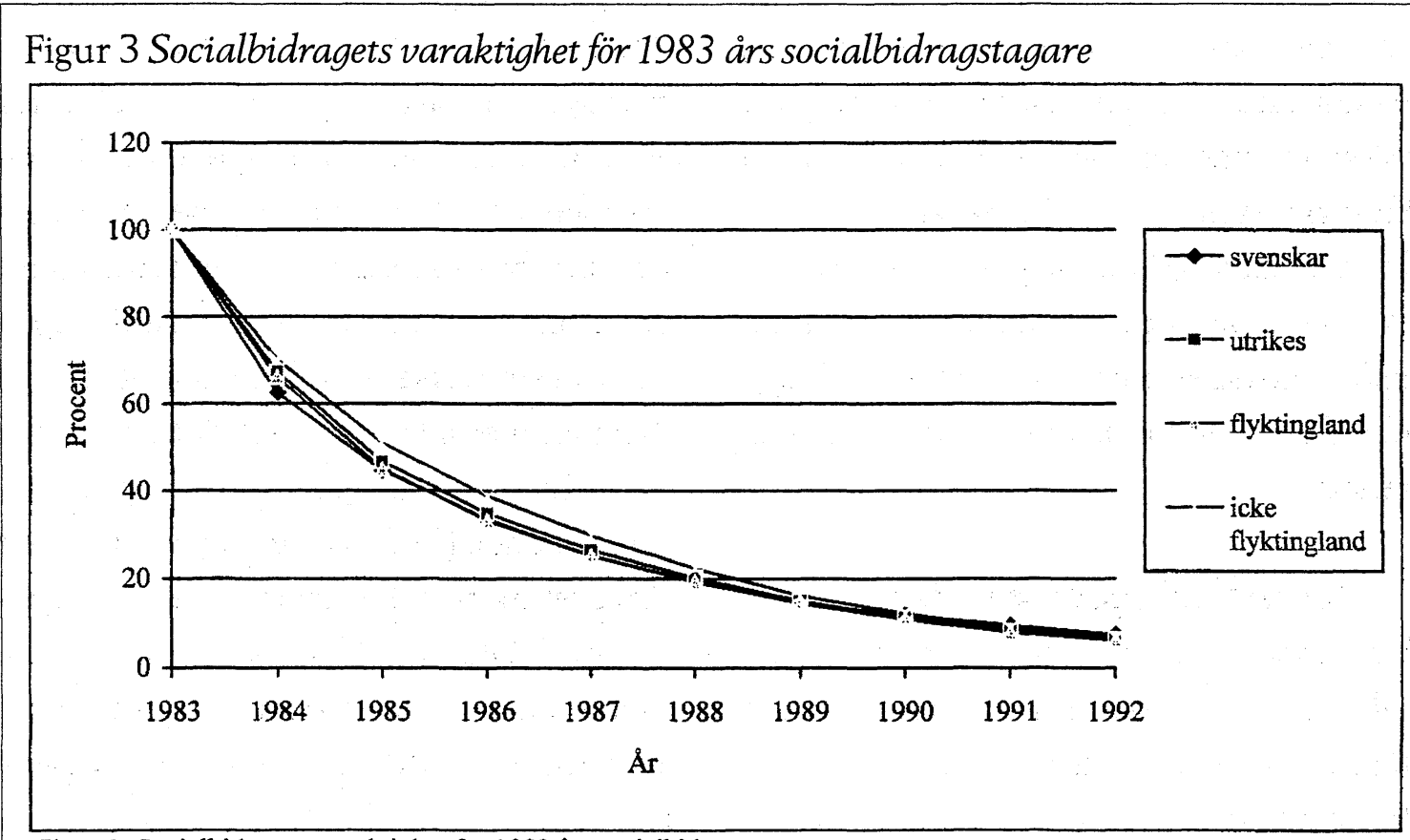

Figur 3: Socialbidragets varaktighet för 1983 års socialbidragstagare 
lyserna visar det sig att få bidragshushåll från Mellanöstern har ett permanent bidragsberoende. Även för dessa hushåll sker en halvering relativt snabbt: redan efter tre år hade hälften av bidragstagarna hittat andra försörjningsmöjligheter.

Socialbidragets tidsmönster kan som tidigare nämnts se mycket olika ut. Vi vet att för många personer är socialbidragsmottagandet endast ett kortvarigt beroende. Oftast är socialbidrag sporadiskt eller återkommande. Om vi återigen följer de socialbidragstagare som mottog bidrag 1983 och dessutom inkluderar de bidragsmottagare som endast någon gång under perioden 1983-92 tagit emot socialbidrag, dvs. även de hushåll som har ett tillfälligt, sporadiskt eller återkommande bidragsbehov. Därmed utökas antalet bidragsmottagare avsevärt. Frågan är den samma som tidigare, dvs. vad händer med bidragsmottagarna om vi följer dessa hushåll under tioårsperioden. Trots att vi denna gång studerar olika bidragsmottagare, oberoende av om bidragstagarna mottar socialbidrag permanent eller sporadiskt mm, framträder samma tendens som tidigare. Resultatet visar att endast en mindre andel av dessa uppbär socialbidrag tio år senare. Vid denna studie framkommer att endast 20-25 procent av socialbidragshushållen tio år senare har socialbidrag. Det är mycket anmärkningsvärt att skillnader saknas med avseende på om den enskilde är svenskfödd eller född utom landet. Detsamma gäller om man är flykting eller annan invandrare. ${ }^{11}$

11 Ovanstående studie används ytterligare en gång för en mer detaljerad analys med avseende på ursprungsland. Inte heller den här gång-
De här resultaten visar tydligt att den typiske socialbidragsmottagaren alltså inte är en långvarig bidragsmottagare. Oavsett om den enskilde är svenskfödd eller utrikes född så är rörligheten från ett socialbidragsberoende till annan försörjning stor. Detta gäller även för dem som kommer från typiska flyktingområden. Trots att många av dessa invandrare nyligen har anlänt till Sverige och att de mött relativt stora svårigheter i etableringsfasen har även dessa invandrare förvånande stor rörlighet från bidragsberoende till andra försörjningsalternativ. För de bidragshushåll som studerats här tycks bidragsberoendet i de allra flesta fall vara en mer eller mindre tillfällig lösning.

Socialbidragsdynamiken kan analyseras med hjälp av flera metoder. Ovan har presenterats en dynamisk aspekt av socialbidragstagandet. Under senare tid har studier av fattigdomsdynamiken blivit ett livligt forskningsfält och en annan metod som numera flitigt används för att studera riskerna att förbli socialbidragstagare är att beräkna den s.k. hazardfunktionen ${ }^{12}$ (Gustafsson \& Voges 1996, Voges \& Rohwer 1992). Därmed kan det konstateras att det finns mycket mer att säga om dynamiken i bidragsmottagandet vad gäller svenska och utländska hushåll. Detta är något som behöver studeras i framtiden.

en framkommer några större avvikelser för olika ursprungsländer. Intressant är att andelen hushåll från Mellanöstern som under observationsperioden någon gång mottagit socialbidrag är något lägre än för nordbor.

12 Hazardfunktionen innebär att bidragsperiodernas sannolika varaktighet beräknas 


\section{Kohortaspekten}

Invandrarens framgång $\mathrm{i}$ det nya landet ökar typiskt i takt med tiden. Efter bosättningstiden skaffar invandraren nödvändiga kontakter och erfarenheter som bidrar till hans möjligheter att kunna försörja sig själv. Sambandet mellan invandrarens bidragstagande och vistelsetid i Sverige kan närmare studeras om analysen utgår från invandringsåret. Detta kan här för första gången presenteras genom att det empiriska materialet innehåller information om både födelseland och invandringsår.

I figur 4 visas fem olika invandringskohorters socialbidragsmottagande under observationsperioden 1983-92. Figuren visar att det finns ett mycket tydligt samband mellan hur många år invandraren va- rit i Sverige och socialbidragstagandet. Ju längre tid i landet desto lägre andel mottar socialbidrag. Detta gäller oavsett invandringsår.

Ett mycket intressant resultat är att först när invandraren har vistats $i$ landet $i$ 15 år är bidragsberoendet jämförbart med de svenskföddas. Personer som är nykomlingar i landet har som förväntat ett högt socialbidragsberoende. Både 1983 års och 1988 års invandringskohorter har ett mycket högt socialbidragsberoende under de första åren i Sverige. De olika invandringskohorternas förutsättningar för en integration i Sverige bedöms ha sett mycket olika ut. De tidigaste anlända, 68- och 73 år invandringskohorter, kom till Sverige i en tid då utländsk arbetskraft efterfrågades och där de aktivt rekryterades till Sverige. Ef-

Figur 4 Socialbidragstagande inom respektive invandringskohort 1983-92

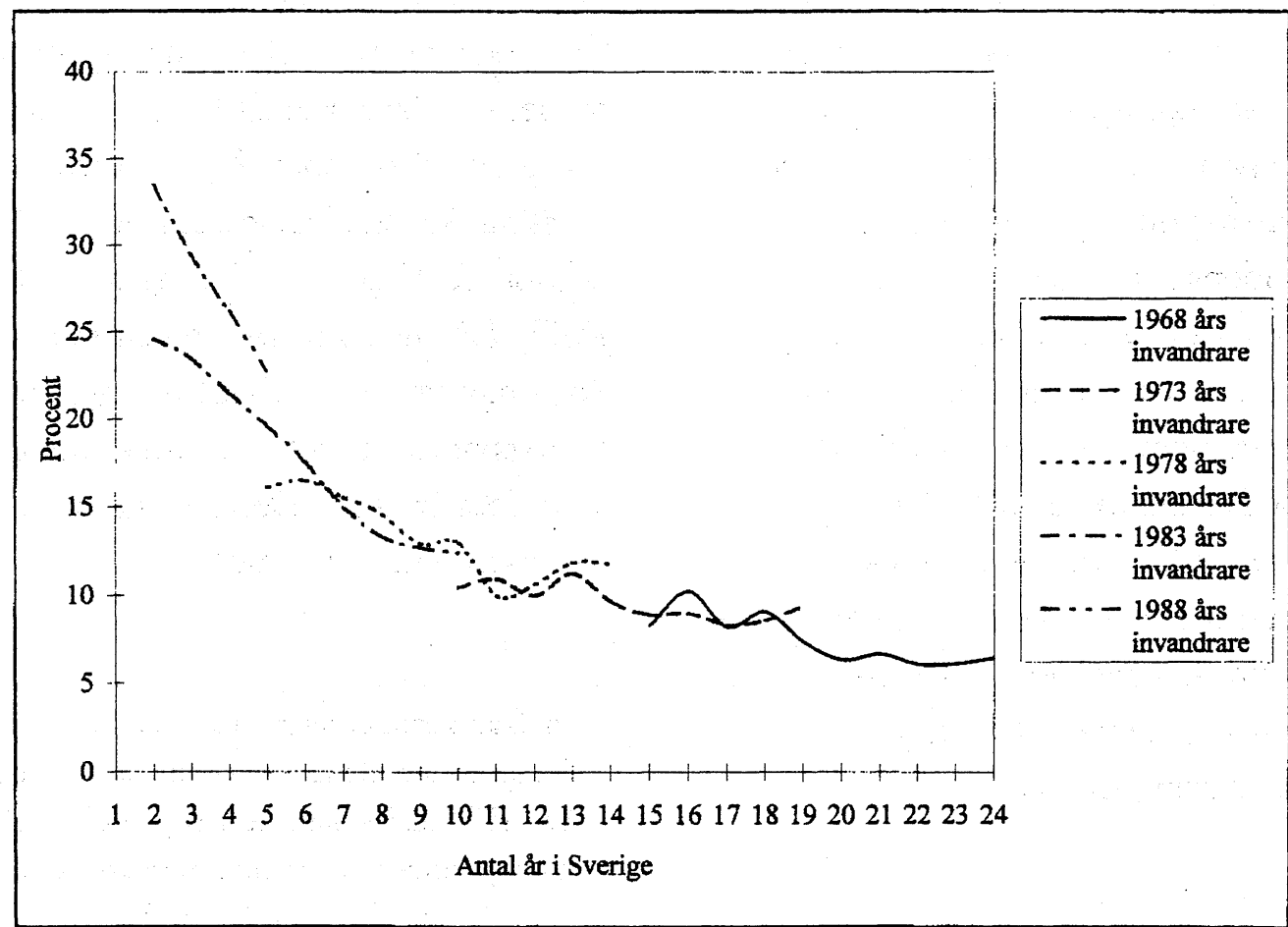

Figur 4: Socialbidragstagande inom respektive invandringskohort 1983-92 
ter det att Sverige började reglera invandringen 1976 har i princip endast flyktinginvandring och anhöriga till invandrare beviljats uppehållstillstånd. Denna förändring innebär för Sveriges del helt nya kulturella och etniska grupper. De strukturella förändringar som skett på arbetsmarknaden under de senaste decennierna innebär dessutom betydligt större svårigheter för de senare invandrarna än vad de tidigare invandrargrupperna drabbats av.

Trots en dramatiskt försämrad arbetsmarknad avtar socialbidragmottagandet $\mathrm{i}$ takt med vistelsetiden även för de senaste anlända invandrarna. Tidigare har visats att ursprungslandet har betydelse för graden av socialbidragsmottagande. Personer som kommer från flyktingländer har generellt sett högre sociabidragsandel än dem från andra länder. Det är därmed intressant att jämföra dessa två kategorier av ursprungsländer och vad som sker efter ett antal vistelseår i Sverige. Det visar sig då, som konstaterats tidigare, att personer från flyktingländer har dubbelt så högt socialbidragsmottagande under de första åren i Sverige som personer från andra länder. Socialbidragsmottagandet sjunker för båda dessa grupper allt eftersom antal år i Sverige ökar. Detta kan tolkas som att efter tio, tolv år har differensen mellan dessa två grupper i det närmaste försvunnit. Studerar vi tidigare invandringskohorter, t.ex. de som kom till Sverige 1968 eller 1973 finner vi samma mönster, dvs. det finns inga skillnader mellan flyktingar och andra invandrare i ett längre tidsperspektiv.

Oavsett ursprung och invandringsår tar det tid för invandrarna att finna andra försörjningskällor. Efter det att det statliga s.k. generalschablonsbidraget infördes som en ersättning till kommunerna för de kostnader som uppkommer i samband med flyktingmottagandet beräknas en introduktionsperiod på ungefär tre år. Efter dessa tre år bedöms flyktingarna vara integrerade eller åtminstone inte i större utsträckning än övriga medborgare vara i behov av socialbidrag för försörjningen. Tvärtom visar resultatet från denna undersökning att invandrare är i betydligt högre grad och under längre tid i beroende av socialbidrag. Introduktionsperioden är lång för invandraren som ska integreras i Sverige. Dessutom är sannolikheten stor att introduktionsperioden förlängs ytterligare på grund av 90-talets strukturarbetslöshet som dramatiskt förändrat nyanlända invandrares sysselsättningsmöjligheter.

\section{Ursprungsdimensionen}

Vi har hittills sett att socialbidragsmottagandet skiftar beroende på om bidragsmottagaren är född i Sverige eller utrikes född. Men eftersom de utrikes födda är en mycket heterogen grupp kan det vara intressant att studera de utrikes födda mer detaljerat beroende på ursprungsland. Tidsserien i figur 5 visar tydligt att bidragsberoendet varierar kraftigt bland de utrikes födda.

Det är knappast förvånande att de europeiska invandrarna har ett betydligt lägre bidragsberoende än utomeuropeiska invandrare. De europeiska invandrarna kom till Sverige som arbetskraftsinvandrare och har dessutom varit i landet under en väsentligt längre tid än dem som kommer från andra kontinenter. Men bryter vi upp ovanstående regioner i detaljerade analyser 
Figur 5 Andelen socialbidragshushåll i olika ländergrupper

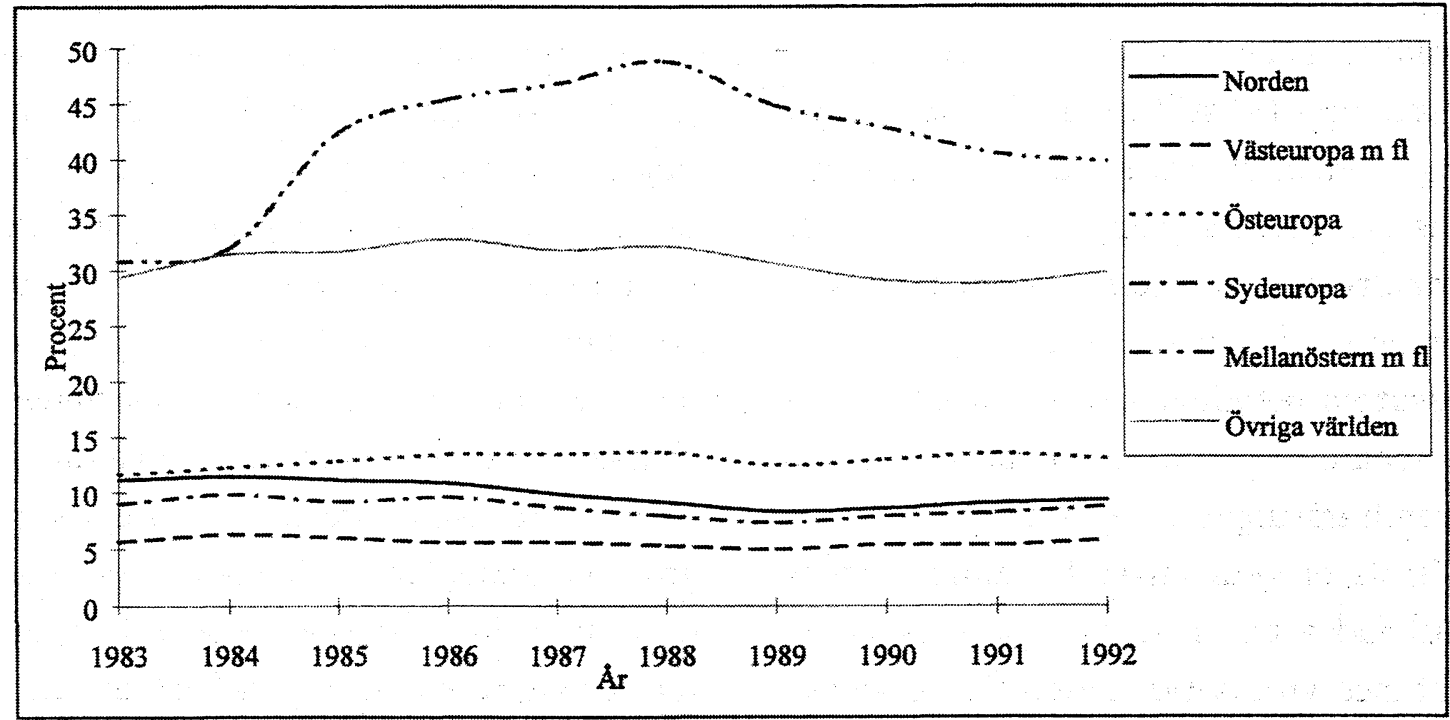

Figur 5: Andelen socialbidragshushåll i olika ländergrupper

så framkommer en mer komplicerad bild. Bland de utomeuropeiska framträder stora skillnader mellan olika länder, från t.ex. länder som Iran, Irak och Etiopien där andelen bidragsmottagande är högst med i genomsnitt 50 procent, till den andra ytterligheten där vi finner länder som Sovjetunionen och USA med endast 5 procent bidragsmottagare. En lika mångfacetterad bild framkommer bland de europeiska invandrarna. Invandrare från ett antal länder har ett relativt lågt socialbidragsberoende. Detta gäller framför allt nordiska samt sydoch västeuropeiska invandrare. Däremot avviker t.ex. invandrare från Östeuropa med ett betydligt högre bidragsberoende.

Stora variationsmönster kan också skönjas bland de utrikes födda om man studerar det åldersspecifika bidragsberoendet. I tabell 3 ser vi att de västeuropeiska invandrarna har ett relativt lågt bidragsmottagande i samtliga åldersgrupper. De har, liksom de nordiska invandrarna, ett fåtal äldre personer som är beroende av bidrag. Däre- mot förtjänas att uppmärksammas att en relativt stor andel yngre nordbor mottar socialbidrag. Det samma gäller även yngre personer från Östeuropa. För de flyktingområdena, Mellanöstern och s.k. övriga världen, är bidragsberoendet högt oavsett ålder. Det är extremt högt bland den äldre befolkningsgruppen. Dessa personer tenderar dessutom att kvarstå som socialbidragstagare under hela levnaden. För dessa äldre personer är socialbidraget nästan den enda inkomstkällan. Beräkningar från materialet visar att socialbidraget för dessa utgör 80 procent av den disponibla inkomsten.

Tidigare konstaterades att i ett längre tidsperspektiv, dvs. då invandrarna varit $\mathrm{i}$ landet ungefär tio år, minskar skillnaden i socialbidragstagande mellan olika invandrargrupper. Som exempel kan två stora invandringsländer studeras: Iran och Finland. Dessa två länder kan karakterisera ett typiskt flyktingland och annat invandrarland. Vid årliga tvärsnittsdata kan note- 


\begin{tabular}{|c|c|c|c|c|c|c|}
\hline $\begin{array}{l}\text { Årsgenomsnitt för } \\
\text { perioden 1983-92 }\end{array}$ & $\begin{array}{c}\text { 18-30 år } \\
\text { antal }\end{array}$ & $\begin{array}{c}18-30 \text { år } \\
\%\end{array}$ & $\begin{array}{l}31-60 a ̊ r \\
\text { antal }\end{array}$ & $\begin{array}{c}31-60 \text { år } \\
\%\end{array}$ & $\begin{array}{l}61 \text { år- } \\
\text { antal }\end{array}$ & $\begin{array}{c}61 \text { år- } \\
\%\end{array}$ \\
\hline $\begin{array}{l}\text { Norden } \\
\text { Västeuropa m.fl } \\
\text { Östeurop } \\
\text { Sydeuropa } \\
\text { Mellanöstern m.fl } \\
\text { Övriga världen }\end{array}$ & $\begin{array}{r}9250 \\
1290 \\
2350 \\
1700 \\
9940 \\
7270\end{array}$ & $\begin{array}{c}17,2 \\
9,7 \\
30,0 \\
13,1 \\
42,5 \\
31,7\end{array}$ & $\begin{array}{l}16100 \\
2230 \\
5230 \\
3640 \\
13830 \\
10020\end{array}$ & $\begin{array}{c}9,8 \\
5,9 \\
13,5 \\
7,5 \\
39,2 \\
29,1\end{array}$ & $\begin{array}{l}1190 \\
260 \\
1490 \\
510 \\
1960 \\
1380\end{array}$ & $\begin{array}{c}2,3 \\
1,7 \\
6,1 \\
8,2 \\
54,5 \\
40,7\end{array}$ \\
\hline $\begin{array}{l}\text { Flyktingländer } \\
\text { Icke flyktingländer }\end{array}$ & $\begin{array}{l}13820 \\
17070\end{array}$ & $\begin{array}{l}37,8 \\
18,5\end{array}$ & $\begin{array}{l}20030 \\
30940\end{array}$ & $\begin{array}{l}23,5 \\
11,2\end{array}$ & $\begin{array}{l}3730 \\
3170\end{array}$ & $\begin{array}{l}12,6 \\
4,1\end{array}$ \\
\hline
\end{tabular}

ras att iranier är cirka fem gånger oftare bidragsmottagare än vad finländska invandrare är. Jämförelsen kompliceras dock av att dessa två grupper av invandrare troligtvis har olika vistelsetid i landet. Om vi däremot följer de iranska respektive finländska socialbidragstagarna, som invandrat till landet under åren 1978 till 1980, under en tioårsperiod framkommer ett mycket intressant resultat (figur 6). Till en början visar det sig att de iranska invandrarna har ett bidragsmottagande som är ungefär dubbelt så stort som de finländska invandrarnas. Men efter tio års bosättning i Sverige framkommer en annan bild. Skillnaderna i bidragsmottagandet mellan de båda invandrargrupperna är då borta. Detta resultat pekar mot att flyktinginvandrares socialbidragstagande minskar i takt med vistelsetiden $i$ landet och att de långsamt närmar sig nivån för övriga invandrargruppers bidragstagande.

\section{Summering}

Invandrares socialbidragsmottagande har varit ett omdiskuterat ämne under de se- naste åren. Den offentliga statistiken som baseras på invandrares medborgarskap och årliga tvärsnittsdata över socialbidragstagande har visat att invandrares socialbidragstagande ökat dramatiskt i förhållande till de svenskföddas. Med hjälp av ett empiriskt material som består av ett stickprovsurval av totalbefolkningen, 1 procent av de svenskfödda och 10 procent av de utrikes födda, kan en longitudinell studie genomföras av infödda respektive utländskt födda socialbidragshushåll. Till skillnad från de annars dominerande studierna kan här presenteras en studie av invandrarnas socialbidragstagande, under tioårsperioden 1983-92, där invandrarnas födelseländer är kända. Först med denna information blir det möjligt att belysa invandrares socialbidragsmottagande och att genomföra en jämförelse med den infödda befolkningen. Genom att denna studie baseras på personernas födelseland istället för medborgarskap möjliggörs att invandrares bidragsmottagande kan studeras oavsett om den enskilde blir svensk medborgare eller ej.

Ett huvudintryck är att de utrikes födda är klart överrepresenterade bland socialbi- 


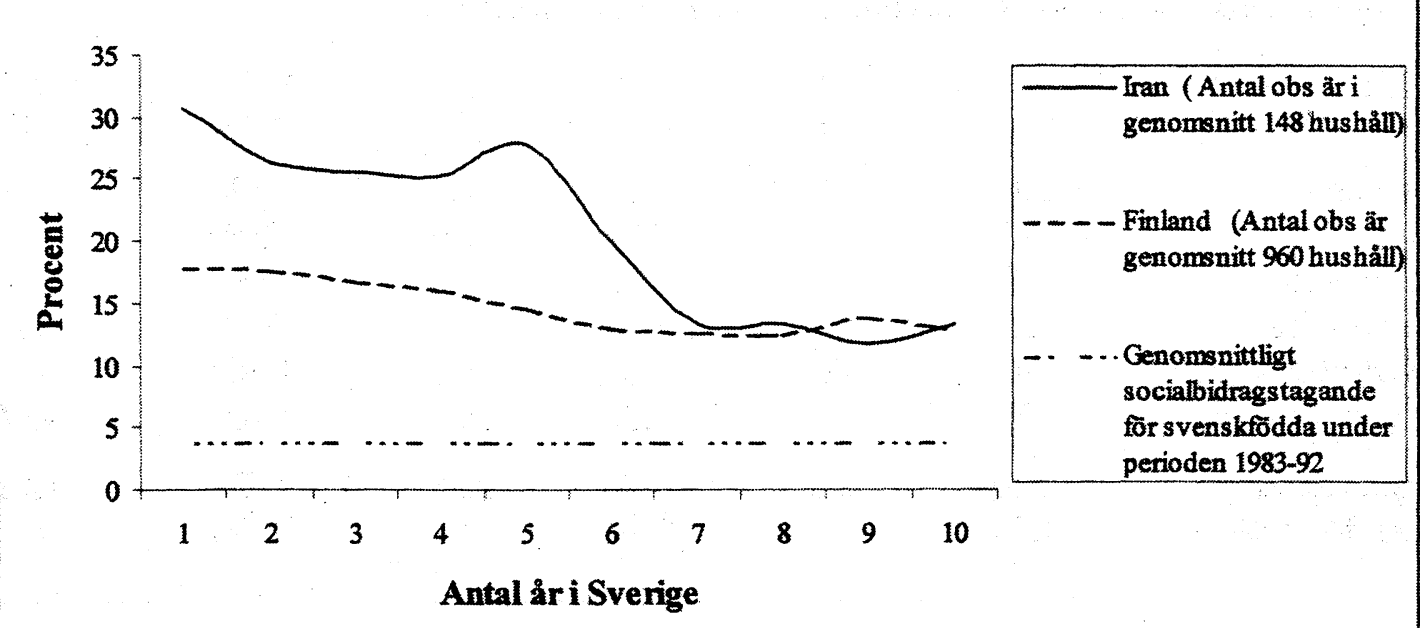

Figur 6: Andelen socialbidragshushåll bland invandringskohorten 1978-80

dragstagarna. Detta gäller oavsett ursprungsland. I genomsnitt är det fyra gånger vanligare att utrikes födda är socialbidragstagare i jämförelse med de infödda. Men den typiske invandraren är inte någon socialbidragstagare. Fem sjättedelar av de utländskt födda är inte mottagare av socialbidrag.

Stor del av invandrargruppens ökade socialbidragstagande kan hänföras till dramatiska förändringar i befolkningsstrukturen. Under 80-talet har ett stort antal invandrare kommit att bosätta sig i landet. Det ökade socialbidragstagandet kan framförallt tillskrivas just dessa nyanlända invandrare. Detta kan konstateras först när befolkningsförändringen konstanthålls. En sådan beräkning visar just en mycket liten proportionell ökning vid samma befolkningsstruktur.

Endast ett fåtal ursprungsgrupper ligger på samma nivåer som den infödda befolkningens. Det är i de yngre åldersgrupperna som socialbidrag är vanligast. Efter- som invandrarbefolkningens åldersstruktur är annorlunda än den inföddas kan en mer rättvis bild ges vid åldersspecifika jämförelser. Vid en sådan jämförelse förändras överrepresentationen av utrikes födda till tre gånger de inföddas andel.

Resultaten visar att det tar tid för en invandrare i Sverige att skaffa sig en egen försörjning. Detta gäller oavsett invandringsår och skäl till invandringen. Det finns en tydlig tendens att vistelsetiden $i$ landet påverkar möjligheterna till egen försörjning positivt. Efter cirka 15 år i landet har invandrare socialbidrag i samma grad som infödda.

Detta skiljer sig markant från t.ex. de amerikanska erfarenheterna. I USA finner man ett motsatt förhållande, dvs. att ju längre tid i landet desto fler blir bidragsmottagare. En förklaring som framhålls till detta kan vara att invandrarna i USA fruktar repressalier i form av deportation vid bidragsutnyttjande och väljer först efter att ha erhållit säkerhet i form av medbor- 
garskap att ansöka om socialbidrag. Men liksom i de amerikanska studierna finner vi i Sverige att bidragsberoendet varierar kraftigt mellan olika invandringsgrupper. I Sverige har invandrare från länder som kulturellt och geografiskt ligger långt från Sverige ett betydligt högre bidragsmottagande än andra invandrare. Men det pekar mot att det höga socialbidragstagandet till viss del kan förklaras av att just dessa invandrare har den kortaste vistelsetiden $\mathrm{i}$ landet. I takt med tiden skaffar invandraren sig de erfarenheter som behövs för att konkurrera på den nya arbetsmarknaden. Detta visas av det empiriska materialet där olika invandrargrupper kunnat följas under tio års tid. Resultatet visar att även invandrare från kulturellt avlägsna områden efter en introduktionsfas på cirka tio år lyckas minska bidragsberoendet till en nivå som kan jämställas med andra invandrargrupper. Med andra ord går det långsammare för flyktingar än för andra invandrargrupper att komma i egen försörjning. Men resultaten pekar entydigt mot att skillnaderna mellan grupperna avtar i takt med ökad vistelsetid i landet för att till slut försvinna.

Under de senaste åren har de allra flesta invandrare kommit till landet som flyktingar. Kommunernas extra kostnader för socialbidrag mm för dessa personer kompenseras av statsbidrag som i stort sett avser att täcka kostnaderna för de första tre åren $i$ kommunen. Därefter bedöms flyktingarna vara ekonomiskt integrerade. I Invandrarpolitiska kommittén föreslås att selektiva åtgärder till invandrare ska begränsas till fem år. Resultaten i den här undersökningen visar att det krävs betydligt längre tid innan flyktingars socialbidragsmottagande kan jämställas med andra invandrargruppers och med de inföddas. Här visar de empiriska resultaten att det tar tre gånger längre tid än vad som sägs av Invandrarpolitiska kommittén, dvs. cirka 15 år, för invandrares socialbidragsberoende ska kunna jämföras med svenskföddas. Resultatet pekar visserligen på att socialbidragsberoendet minskar i takt med tiden även för flyktingar men att senare anlända grupper har stora svårigheter med att bli självförsörjande.

Studien bekräftar att de allra flesta hushåll erhåller dock socialbidrag högst tillfälligt. Få hushåll har således ett kontinuerligt bidragsbehov. Detta gäller både svenska och utländska bidragshushåll. Resultaten visar också att detta gäller oavsett ursprungsland. Rörligheten, från att vara beroende av socialbidrag till att ha någon form av annan försörjning, är stor. Något förvånande framkommer att även utländska bidragsmottagare, oavsett om den enskilde är flykting eller ej, relativt snabbt kommer ur ett kontinuerligt bidragsberoende och hittar andra försörjningsalternativ. Detta visar sig först då olika socialbidragshushåll kan följas under en följd av år. Socialbidragstagandets varaktighet, då det mäts på detta sätt, visar sig då inte påverkas av om den enskilde är svenskfödd eller utrikes född.

En allmän slutsats är att socialbidraget inte längre riktar sig till en marginell grupp i samhället. Allt fler grupper av befolkningen har någon gång varit mottagare av socialbidrag. Erfarenheten av socialbidrag bland invandrargruppen måste bedömas som omfattande. Detta framkommer först 
i analyser där observationstiden förlängs. Under en tioårsperiod visar det sig att cirka 10 procent av de svenskfödda samt 25 procent av de utrikes födda hushållen har socialbidragserfarenhet.

Slutligen bör det poängteras att det är angeläget att vidareutveckla analyser av invandrares socialbidragstagande och jämförelser med den infödda befolkningen för att uppmärksamma i vad mån invandrargruppens försörjningssituation relativt försämrats. För att kunna belysa invandrares socialbidragssituation krävs det ytterligare studier som beaktar invandrargruppens flerdimensionalitet samt en jämförelse av i övrigt lika svenskfödda. Dessutom krävs att socialbidragsmottagandets kontextuella sammanhang studeras, dvs. hur socialbidragets funktion och utformning påverkar invandrargruppens bidragsmottagande.
Det är dock ingen självklarhet att situationen för de invandrare som kommit till Sverige under 90-talet förbättras i samma takt som tidigare invandringsgrupper. Förändringen på arbetsmarknaden har dramatiskt förändrat möjligheten för arbetslösa att erhålla en egen försörjning. Det finns all anledning att befara att de strukturella förändringar som skett $\mathrm{i}$ landet under senare tid också försvårar integrationen och att senare anlända invandrare möter. större svårigheter än sina föregångare. Man kan förmoda att 90-talets försämringar på arbetsmarknaden även drabbar de gamla invandrargrupperna. Därför är det angeläget med fortsatta studier av 90-talets socialbidragsutveckling.

Tack!

Jag vill tacka Torun Larsson för värdefull hjälp.

\section{Summary \\ Social assistance among immigrants}

Social assistance among immigrants in Sweden has been hotly debated. The focus has been on whether immigrants receive social assistance on a permanent basis or if they manage to succeed and earn their own living after due time in the new country. Today's accumulated knowledge of social assistance to immigrants is almost without exception based on the person's citizenship. This article has the advantage of being built on the immigrant's land of origin. The study is based on two random samples from Sweden's statistical register of the population; 1 percent of the Swedish born-population and 10 percent of the recently arrived foreign-born population.

The variation and dynamics among the recipients will be closely observed over a ten-year period, 1983-92. The principal ambition is to answer two questions: how quickly can immigrants be rid of social assistance dependency in relation to the time spent in the new country, and whether different groups of immigrants meet different difficulties when they try to rid themselves of social assistance dependency.

One main impression of the analysis is 
that the foreign-born immigrants are highly represented among social assistance recipients. This is irrespective of their land of origin. On average, the foreign-born immigrant is four times more frequently. represented than the native born Swede. The most frequent occurrence of social assistance is found among the youngest share of the population. As the age distribution among immigrants differs from that of the native-born Swedes, a more representative picture can be given when age is taken into account. The comparison then shows a three times higher representation as compared to native Swedes.

In contrast to the situation in America foreign-born social assistance recipients in Sweden are positively influenced by the time spent in the country. This study shows that after 15 years in the country the immigrant's level of social assistance is comparable to that of a native Swede. This is irrespective of motives or years of immigration. There is, however, no guarantee that the situation for immigrants who arrived in the 1990s is as good as that of those who arrived earlier.

The study confirms that most of the households receive social assistance only temporarily. This applies to both native and foreign households. A great mobility from social assistance dependency to selfsufficiency is to be seen. There is no difference observed as regards to country of origin or whether the recipient is a refugee or had other motives for immigrating.

\section{Referenser}

Baker \& Benjamin (1994) The Receipt of Transfer Payments by Immigrants to Canada, The Journal of Human Resources Vol. XXX (4) p. 650676

Blom, Svein (1996) Inn i samfunnet? Statistisk sentralbyrå 96/5

Borjas, G\& Trejo, S (1991) Immigrant Participation in the Welfare System, Industrial and Labor Review, Vol. 44 p. 195-211

Borjas, G(1995) Immigation and Welfare 19701990, Research in Labor Economics, Vol. XIV p. 253-282

Borjas, G \& Hilton, L (1996) Immigration and the Welfare State: Immigrant participation in means-tested entitlement programs, Quarterly Journal of Economics Vol p. 575-603

Diaz, Jose A (1993) Choosing integration, Uppsala Universitet

Eardley, T., Bradshaw, J., Ditch, J., Gough, I., och Whiteford, P. (1996) Social Assistance in
OECDCountries: Country Reports, Department of Social Security Research Report No 47, London: HMSO.

Ekberg, J \& Gustafsson, B (1995) Invandrare påarbetsmarknaden, Stockholm, SNS-förlag

Ekberg, J (1993) Sysselsättning och arbetsmarknadskarriär bland invandrare. Rapport till Invandrar- och flyktingkommitten, Kulturdepartementet, Stockholm

Ekberg, J \& Andersson, L (1995) Invandring, sysselsättning och ekonomiska effekter, Ds 1995:68 ESO, Finansdepartementet, Stockholm

Gustafsson, B (1984) En bok om fattigdom, Lund; Studentlitteratur

Gustafsson, B (1986) Bidragstagarna: antal och inkomster, i Socialbidrag, Ds Fi 1986:16, Finansdepartementet, Stockholm

Gustafsson, B (1986b) International Migration and Falling into the Income Safety Net , International Migration, Vol. XXIV (2) 
Gustafsson, B., Zamanian, M \& Aguilar; R (1990) Invandrare och försörjning, Göteborg; Daidalos

Gustafsson, B (1996) Fattigdom i Sverige. Förändring åren 1975 till 1993, struktur och dynamik, i Nordiska ministerrådet, Den nordiska fattig domens utveckling och struktur, Köpenhamn, Tema Nord 1996:583

Gustafsson, B (1997) Invandrarnas försörjning, $\mathrm{i}$ Maingfald och ursprung, Statens Invandrarverk

Halleröd, B (1991) Den svenska fattigdomen, Lund: Arkiv

Hjern, A (1995) Migrationsmedicinsk forskning. En översikt, Medicinska forskningsrådet, MFR-rapport 1

Invandrarpolitiska kommittén (1996) Sverige, framtiden och mångfalden, SOU 1996:55

Jensen, L (1988) Patterns of Immigration and Public Assistance Utilization, 1970-1980, International Migration Review Vol. XXII p. 51-83

Riksförsäkringsverket (1996) Invandrarna i social- försäkringen, sjukskrivning, rehabilitering och förtidspensionering under 1990-talet, Stockholm: RFV Redovisar 1996:11

Salonen, Tapio (1993) Margins of welfare, Hällestad; Hällestads Press

Socialstyrelsen (1995) Socialbidragstagare och socialbidragets utveckling, Socialstyrelsen följer upp och utvärderar 1995:4

Socialstyrelsen (1995) Invandrarnas hälsa och sociala förhaillanden, SoS-rapport 1995:5

Soydan, H(1995) Försäkringskassan och invandrarna, Ystad: Bokbox Förlag

Statens Invandrarverk (1997) Mångfald och ursprung

Vassenden, Kåre (1997) Innvandrere i Norge, Statistisk sentralbyrå

Voges W \& Rohwer, G (1992) Receiving social assistance in Germany: risk and duration, Journal of European Social Policy(3) pp 175-191 